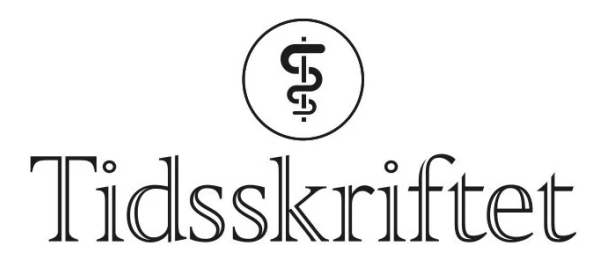

DEN NORSKE LEGEFORENING

\title{
Midtlappstorsjon etter lobektomi
}

\author{
KORT KASUISTIKK
}

JOHAN WANG

johwan@ous-hf.no

Avdeling for radiologi og nukleærmedisin

Oslo universitetssykehus, Ullevål

Johan Wang er lege i spesialisering i radiologi.

Forfatteren har fylt ut ICMJE-skjemaet og oppgir ingen interessekonflikter.

\section{PETER MAJAK}

Thoraxkirurgisk avdeling

Oslo universitetssykehus, Ullevål

og

Institutt for klinisk medisin

Universitetet i Oslo

Peter Majak er ph.d., spesialist i torakskirurgi, overlege og førsteamanuensis.

Forfatteren har fylt ut ICMJE-skjemaet og oppgir ingen interessekonflikter.

\section{PER REIDAR WOLDBAK}

Thoraxkirurgisk avdeling Oslo universitetssykehus, Ullevål

Per Reidar Woldbæk er dr.med., spesialist i torakskirurgi og overlege.

Forfatteren har fylt ut ICMJE-skjemaet og oppgir ingen interessekonflikter.

\section{EIRIK MADSEN}

Avdeling for radiologi og nukleærmedisin

Oslo universitetssykehus, Ullevål

Eirik Madsen er spesialist i radiologi og overlege.

Forfatteren har fylt ut ICMJE-skjemaet og oppgir ingen interessekonflikter.

\section{Lungekreft er den nest hyppigste kreftformen blant kvinner og menn i Norge. Stadig flere pasienter med ikke-småcellet lungekreft blir operert, vanligvis med lobær reseksjon. Vi presenterer en sjelden, men potensielt livstruende komplikasjon etter lobektomi.}

En mann i 70-årene med kjent hypertensjon og type 2-diabetes hadde i løpet av et halvt års tid hatt et ufrivillig vekttap på over $10 \mathrm{~kg}$ og fikk påvist anemi. CT toraks, abdomen og bekken avdekket en ca. $9 \mathrm{~cm}$ tumor i høyre lunges overlapp med infiltrasjon i øvre segment 
av underlappen, samt enkelte forstørrede lymfeknuter i høyre lungehilum og mediastinum. Supplerende positronemisjonstomografi (PET)-CT viste ingen tegn til fjernmetastaser. CT-veiledet biopsi av tumor viste plateepitelkarsinom. Det ble utført endoskopisk bronkial ultralydundersøkelse (EBUS) og mediastinoskopi uten funn av lymfeknutemetastaser. Pasienten var i klinisk stadium IIIA og ble akseptert for operasjon. Det ble utført posterolateral torakotomi og utvidet høyre overlappsektomi med sublobær reseksjon av høyre underlapp. Operasjonen var vellykket og uten spesielle hendelser. Det ble i henhold til rutinene lagt et toraksdren på den opererte siden.

Rutinemessig postoperativ røntgen toraks viste atelektasepregede fortetninger i høyre lunges midtlapp. Det forelå også en liten høyresidig pneumotoraks og små mengder pleuravæske på samme side, som man kunne forvente etter operasjonen. Kontroll med røntgen toraks første postoperative dag viste økte fortetninger i øvre halvdel av høyre hemitoraks, som kunne være uttrykk for forverret atelektase, pleuravæske eller hemotoraks (figur 1). Pasienten var respiratorisk ubesværet og hadde god kapillær oksygenmetning på 96-98 \% med oksygentilskudd 2 L/min på nesekateter. Det forelå ingen kliniske infeksjonstegn.

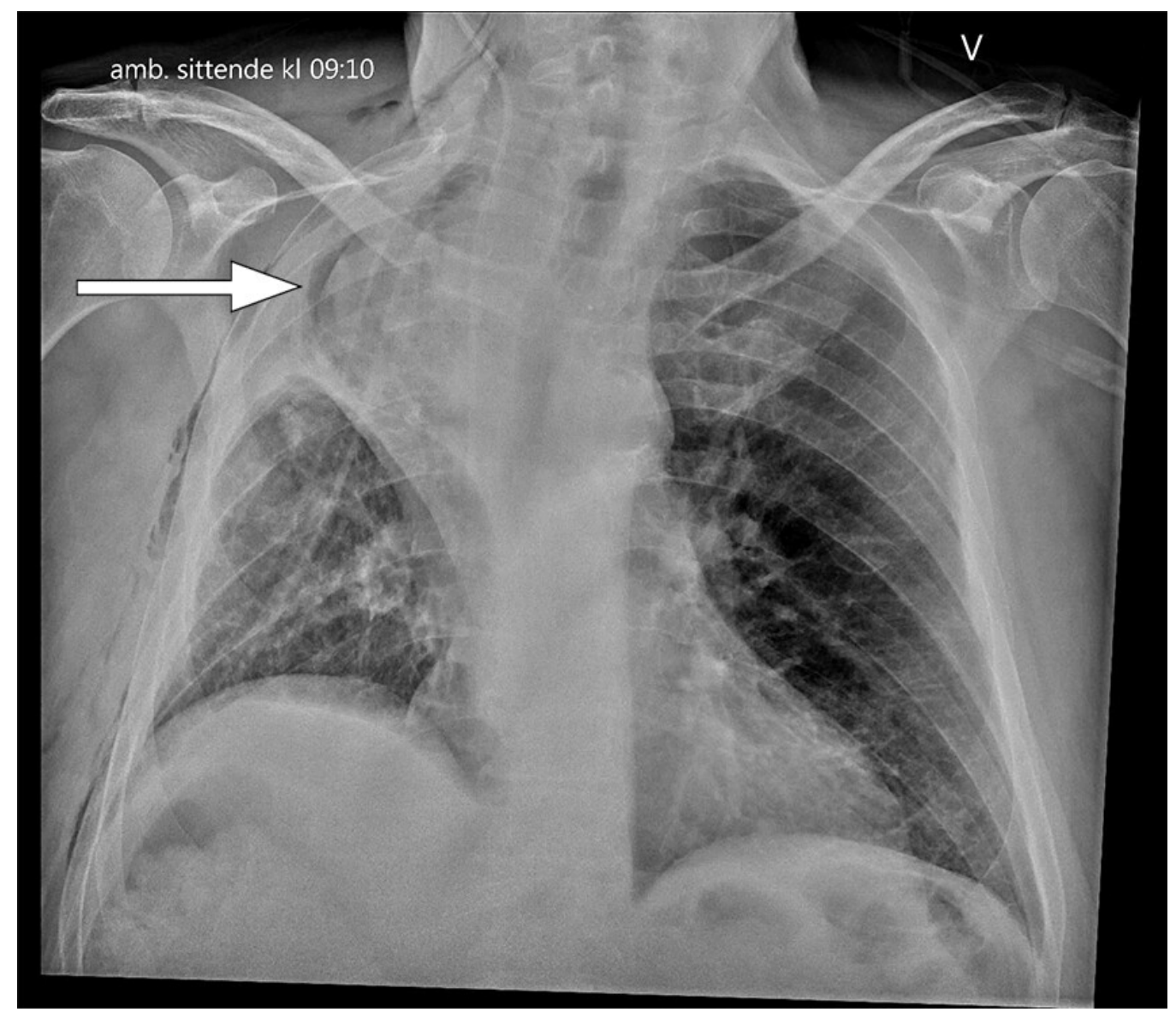

Figur 1 Røntgen toraks frontbilde tatt sittende i seng første postoperative dag etter primæroperasjonen. Bildet viser fortetninger i øvre og midtre høyre lungefelt, som ble tolket som væske projisert over fortetninger i midtlappen. Det var en liten pneumotoraks på høyre side, som forventet postoperativt.

Man mistenkte slimplugg som årsak til atelektasen, og det ble derfor utført bronkoskopi under sedasjon første postoperative dag. Bronkoskopøren mislyktes i å komme inn i midtlappsbronkus fordi den avgikk skarpt vinklet i kranial retning, men ostiet var åpent. Høyre underlappsbronkus var åpen uten påfallende mye slim. Pasienten ble videre behandlet med ikke-invasiv ventilasjonsstøtte (NIV) i form av kontinuerlig positivt luftveistrykk (CPAP).

Grunnet tettere oppfølging ble røntgen toraks utført senere samme dag. Denne viste ikke vesentlig endring. Pasienten ble derfor henvist til CT-undersøkelse for videre diagnostikk. CT toraks med intravenøst kontrastmiddel utført på kveldstid samme dag viste en apikalt 
lokalisert midtlapp med utbredte mattglassfortetninger og områder med konsolidering samt fortykkede interlobulære septa (figur 2). Midtlappen fremsto som nærmest fullstendig devaskularisert. Proksimale midtlappsbronkus var obliterert, og transversale snitt viste subtilt virveltegn (swirl sign) i midtlappen som tegn på vridning. Fra radiologisk hold ble det reist mistanke om torsjon av midtlappen.

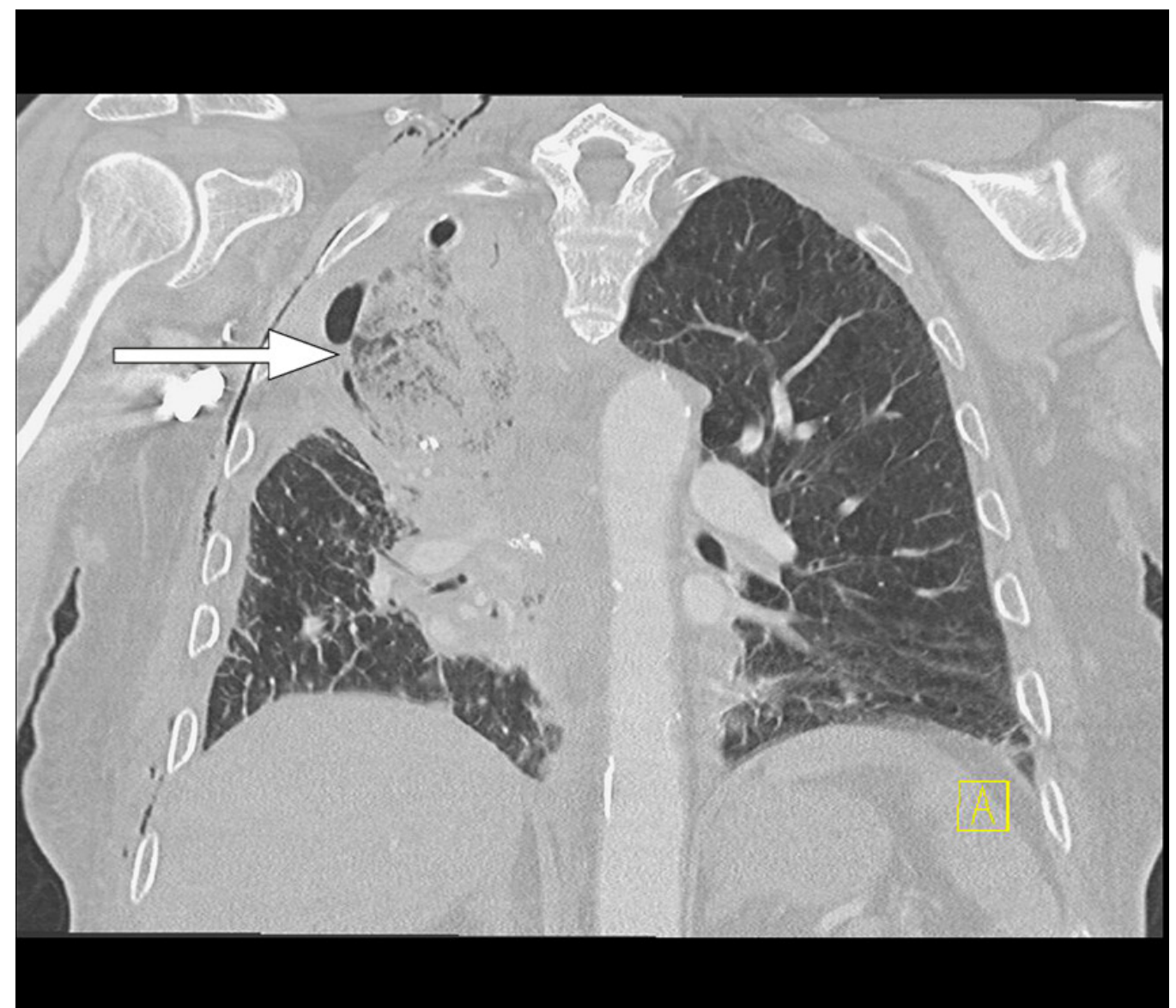

Figur 2 CT toraks med intravenøst kontrastmiddel tatt første postoperative dag etter primæroperasjonen. Koronalt snitt med lungevindu viser mattglassfortetninger, konsoliderte fortetninger og fortykkede interlobulære septa i midtlappen. Det var en liten pneumotoraks og små mengder pleuravæske på høyre side, som forventet postoperativt. Man ser inneliggende toraksdren med tuppen over høyre lungetopp.

Det var indikasjon for eksplorativ torakotomi på grunnlag av radiologiske funn, men grunnet pasientens gode allmenntilstand valgte man å avvente operasjonen til neste morgen. Det ble utført torakotomi gjennom operasjonssåret, og man fant en $180^{\circ}$ torkvert midtlapp med uttalt atelektase og stuvning. Midtlappen ble ikke vurdert som viabel, og det ble foretatt en anatomisk reseksjon. Det per- og postoperative forløpet var ukomplisert. Røntgen toraks senere på operasjonsdagen og de påfølgende dagene viste adekvat ekspansjon av gjenværende underlapp og gradvis avtagende pneumotoraks. Pasienten ble utskrevet til lokalsykehus fjerde postoperative dag etter reoperasjonen.

\section{Diskusjon}

Vår kasuistikk beskriver et tilfelle med midtlappstorsjon etter overlappsreseksjon, med torsjonsgrad på 18o. Lungetorsjon er en sjelden tilstand, med rapportert insidens på o,089\% i en amerikansk studie (1). Postoperativ midtlappstorsjon etter høyre overlappsektomi er vanligste form for lungetorsjon, som hos vår pasient. Tilstanden forekommer som oftest i forbindelse med torakskirurgi, mindre hyppig etter traume eller spontant (1-3). Lungetorsjon omfatter som regel hilære strukturer og kan affisere hele lungen, én eller flere lungelapper eller en del av en lungelapp. Torsjonsgraden er hyppigst 180, men kan variere fra go til 1 o8o (3). 
Vår pasient var asymptomatisk, som er beskrevet hos $21 \%$ ved postoperativ lungetorsjon (3). Vanligste symptomer og funn er akutt innsettende dyspné, feber, brystsmerter og hoste. Under- og feildiagnostikk er vanlig, da symptomer og funn overlapper betydelig med andre postoperative tilstander (3). Den vanligste av disse er obstruktiv atelektase som følge av sekretstagnasjon. Mindre vanlige tilstander er blødning, infeksjon og lungeembolisme. En sjelden komplikasjon er nekrose som følge av iatrogen skade på karstrukturer i affiserte lungelapp.

Hos vår pasient ble det initialt utført bronkoskopi, ettersom vanligste årsak til fortetninger og atelektaser er slimpropp. Under bronkoskopien var det ikke funn av dette, men det var manglende oversikt i midtlappsbronkus uten entydig årsak. I litteraturen er det beskrevet at torsjon kan mistenkes bronkoskopisk ved uvanlig orientert og obstruert bronkus som ikke skyldes sekret.

Røntgen toraks kan gi mistanke om lobær lungetorsjon ved funn av fortetninger i en uvanlig orientert lungelapp som eventuelt endrer posisjon i løpet av kort tid (몬). På CT vil en torkvert lungelapp vanligvis ha redusert kontrastoppladning samt konsoliderte og/eller mattglasspregede fortetninger. En torkvert lapp kan utvikle luftretensjon og stuvning, som medfører henholdsvis ekspansjon av lappen og fortykkede interlobulære septa som uttrykk for interstitielt $ø$ dem. Lappens bronkovaskulære strukturer vil være skarpt obliterert nær lungehilum og kan få endret orientering, som på røntgen. Utviklingen av disse forandringene avhenger av grad og varighet av torsjonen. Hos vår pasient samsvarte radiologiske funn godt med tidligere beskrevne funn i litteraturen.

Vi oppdaget tilstanden uvanlig tidlig på grunnlag av radiologiske funn alene. Median diagnosetid for postoperativ lungetorsjon er 10 (2-14) dager etter primæroperasjonen (3). Selv om en betydelig andel pasienter med postoperativ lungetorsjon er asymptomatiske, tror vi at vår pasient ville ha utviklet symptomer tredje eller fjerde postoperative dag, med utvikling av nekrose og infeksjon i midtlappen.

Ved tilstrekkelig mistanke om torsjon stilles endelig diagnose med kirurgisk eksplorasjon. Behandlingen er detorkvering eller reseksjon av affisert lapp, avhengig av lappens viabilitet.

Lungetorsjon forekommer sjelden. Tilstanden er likevel viktig å kjenne til, da ubehandlet torsjon er potensielt dødelig. Det er imidlertid varierende letalitetsrater i den sparsomme litteraturen som omhandler emnet.

Postoperativ lungetorsjon forekommer ikke nødvendigvis så tidlig etter operasjonen som hos vår pasient, og det kan gå opptil 14 dager før tilstanden manifesterer seg klinisk. Det er derfor viktig å ha kjennskap til tilstanden både på regionsykehus og lokalsykehus som mottar nyopererte pasienter.

\section{Konklusjon}

Lungetorsjon er en sjelden, men potensielt dødelig tilstand som bør mistenkes hos lungeopererte pasienter med akutte nedre luftveissymptomer som ikke responderer adekvat på behandling for vanlige postoperative tilstander eller når disse er utelukket. Tilstanden kan også mistenkes tidlig på grunnlag av radiologiske eller bronkoskopiske funn, som hos vår pasient.

Pasienten har gitt samtykke til at artikkelen blir publisert.

Artikkelen er fagfellevurdert. 


\section{LITTERATUR}

1. Cable DG, Deschamps C, Allen MS et al. Lobar torsion after pulmonary resection: presentation and outcome. J Thorac Cardiovasc Surg 2001; 122: 1091-3. [PubMed][CrossRef]

2. Felson B. Lung torsion: radiographic findings in nine cases. Radiology 1987; 162: 631-8. [PubMed] [CrossRef]

3. Dai J, Xie D, Wang H et al. Predictors of survival in lung torsion: A systematic review and pooled analysis. J Thorac Cardiovasc Surg 2016; 152: 737-45.e3. [PubMed][CrossRef]

4. Childs L, Ellis S, Francies O. Pulmonary lobar torsion: a rare complication following pulmonary resection, but one not to miss. BJR Case Rep 2017; 2: 20160010. [PubMed][CrossRef]

Publisert: 10. desember 2021. Tidsskr Nor Legeforen. DOI: 10.4045/tidsskr.21.0150

Mottatt 24.2.2021, første revisjon innsendt 8.6.2021, godkjent 27.6.2021.

Publisert under åpen tilgang CC BY-ND. Lastet ned fra tidsskriftet.no 26. april 2023. 